\title{
The Effect of Dispersal Ability in Winter and Summer Stoneflies on their Genetic Differentiation
}

\author{
Alison L. Yasick \\ Cleveland State University \\ Robert A. Krebs \\ Cleveland State University, r.krebs@csuohio.edu \\ Julie A. Wolin \\ Cleveland State University, j.wolin@csuohio.edu
}

Follow this and additional works at: https://engagedscholarship.csuohio.edu/scibges_facpub

Part of the Biology Commons

How does access to this work benefit you? Let us know!

\section{Publisher's Statement}

This is the accepted version of the following article: YASICK AL, KREBS RA, WOLIN JA. 2007.

The effect of dispersal ability in winter and summer stoneflies on their genetic differentiation.

Ecol Entomol 32(4):399-404 which has been published in final form at

http://onlinelibrary.wiley.com/doi/10.1111/j.1365-2311.2007.00881.x/abstract

\section{Recommended Citation}

YASICK AL, KREBS RA, WOLIN JA. 2007. The effect of dispersal ability in winter and summer stoneflies on their genetic differentiation. Ecol Entomol 32(4):399-404.

This Article is brought to you for free and open access by the Biological, Geological, and Environmental Sciences Department at EngagedScholarship@CSU. It has been accepted for inclusion in Biological, Geological, and Environmental Faculty Publications by an authorized administrator of EngagedScholarship@CSU. For more information, please contact library.es@csuohio.edu. 


\title{
The effect of dispersal ability in winter and summer stoneflies on their genetic differentiation
}

\author{
ALISON L. YASICK, ROBERT A. KREBS and JULIE A. WOLIN \\ Department of Biological, Geological and Environmental Sciences, Cleveland State University, Cleveland, Ohio, U.S.A.
}

\begin{abstract}
Plecopteran species disperse less than most other aquatic insects. Within stoneflies, members of different families vary in the degree of wing morphology and season of adult emergence.

2. Dispersal limitations were tested to determine if there were increased differences among the nearby, Chagrin and Grand River populations in north-eastern Ohio, by comparing genetic variation within the 16s rRNA region of mitochondrial DNA in two stoneflies. Allocapnia recta emerges in winter and often has rudimentary wings, and Leuctra tenuis emerges in summer with fully developed wings.

3. There was significant genetic variability between the samples of $A$. recta from two adjacent rivers $(\mathrm{FST}=0.20)$, but not between samples of $L$. tenuis $(\mathrm{FST}=0.07)$.

4. Distinct clades in A. recta were found to occur within the minimum spanning tree specific to the Chagrin River, which contributed to a significant difference in gene diversity between the two rivers. Haplotypes in L. tenuis appeared randomly distributed between the two rivers; however, nucleotide diversity was significantly less in samples from the Grand River.

5. Shared haplotypes of both species illustrate the inter-connectedness of the Chagrin and Grand River populations, and the lower genetic variability of L. tenuis between the two rivers is indicative of its greater dispersal capability.
\end{abstract}

Key words. Allocapnia recta, dispersal, genetic drift, haplotype diversity, Leuctra tenuis, stoneflies, 16s rRNA region.

\section{Introduction}

Dispersal ability of organisms is a key ecological factor that influences the structure of a population (Miller et al., 2002). In freshwater communities, genetic divergence may arise because a stream system flows through several habitats, each habitat acting effectively as a biogeographic barrier from either a location within the stream or other near-by watersheds (Monaghan et al., 2002; Monaghan et al., 2005). Isolation by physical barriers in combination with genetic drift, or differing pressures of natural selection within each habitat has the potential of increasing genetic divergence between streams (Monaghan et al., 2002).

Most flying aquatic insects can navigate between adjacent rivers (Petersen et al., 2004). There are, however, some species that possess wings, but have limited flight. Sanderson et al. (2005) noted that the composition of communities from neigh-

Correspondence: Alison L. Yasick, Department of Biological, Geological, and Environmental Sciences, Cleveland State University, 2121 Euclid Avenue, Cleveland, OH 44115, U.S.A. E-mail: a.yasick@ csuohio.edu bouring streams were generally similar, with some differences observed in weak dispersers such as Ephemeroptera. Smith et al. (2006) similarly reported population divergence in mayflies across catchments, although differences between adjacent streams were less. Stoneflies (Order: Plecoptera), however, are even weaker fliers (Nebeker \& Gaufin, 1967) than mayflies, and therefore their movement among river systems is more likely to be inhibited by habitat fragmentation than that of stronger flying insects. Schultheis et al. (2002) identified greater movement of Peltoperla tarteri (Stark \& Kondratieff) within streams as opposed to among streams in the Southern Appalachians. In western Montana, Hughes et al. (1999) similarly identified population variation in Yoraperla brevis (Ricker). High gene flow within streams is possible because larvae can disperse downstream, but long distance dispersal between streams requires adult flight (DePietro et al., 1997; Hughes et al., 1999). Therefore, understanding a stream's ecosystem requires not only the assessment of diversity on a community level, but also knowledge of population structure and morphology as they relate to the landscape (Bohonak \& Jenkins, 2003). 
To test the effect of low dispersal, genetic divergence was examined in Allocapnia recta (Claassen) and Leuctra tenuis (Pictet), two Plecopteran species that vary in wing morphology and emergence period (Gaston, 1994 and Malmqvist, 2000). Allocapnia recta emerge during the coldest time of year between November and March. Although some A. recta males and females have wings the full length of their body, they are commonly collected as apterous or with rudimentary wing structure (Frison, 1942; Nebeker \& Gaufin, 1967; Stark et al., 1998). Leuctra tenuis emerge between July and September, when the weather is warmer. Adults in the family Leuctridae are relatively stronger fliers at warmer temperatures than other stonefly species (Briers et al., 2004).

\section{Materials and methods}

Adult specimens of Allocapnia recta (Family Capniidae) and Leuctra tenuis (Family Leuctridae) were collected along the Chagrin and Grand Rivers, two adjacent tributaries of Lake Erie on Ohio's north coast (Fig. 1). Collections were made between 2003 and 2005. Allocapnia recta was obtained from November to February and L. tenuis from June to August. Specimens were collected within $15 \mathrm{~m}$ of the stream. Specimens of Allocapnia recta were collected as the insects were observed crawling on the snow. A beating sheet was used to collect $L$. tenuis from low hanging tree limbs or from ground vegetation.

Each individual specimen was placed in a $1.5 \mathrm{ml}$ microcentrifuge tube containing $95 \%$ ethanol. If a male and female were captured in copula, the mating pair was placed in the same tube.

Collected specimens were identified to species based on the structure of the male genitalia (Ross \& Ricker, 1971). The lower abdomen was removed from the male specimens and stored for species documentation. The only females used in this study were those found associated with a male in the field.
Each stonefly, less the lower abdomen, was soaked in distilled water for $10 \mathrm{~min}$ to remove ethanol. DNA was isolated using the QIAGEN DNeasy ${ }^{\circledR}$ Tissue kit (Qiagen, Valencia, CA) and applying the rodent tail tissue protocol (following methods from Schultheis et al., 2002). An elution of $100 \mu \mathrm{l}$ was used to increase DNA concentration.

The 16s rRNA gene, which codes for the large mitochondrial ribosomal subunit, was used to assess levels of genetic differentiation at the population level. Universal animal primers of the 16s rRNA gene amplified an approximate $500 \mathrm{bp}$ long region of the mitochondrial DNA (mtDNA). The forward primer $(16 \mathrm{sB})$ was $5^{\prime}$-CCG GTT TGA ACT CAG ATC ATG T-3' and the reverse (16sA) was 5'-CGC CTG TTT AAC AAA AAC AT-3' (Palumbi, 1997; optimised for insect use). In the stonefly specimens, the universal primers produced a faint 100-200 bp secondary product that interfered with sequencing quality. Therefore, internal primers were developed specifically for each species to improve sequencing. For $A$. recta the forward primer was (SF_arF) 5'-TCG AAC AGA CCT AAA CTT TG-3' and the reverse was (SF_arR) 5' -AAT AAT TTA AAG TCT GAC CTG C-3'. For L. tenuis the forward primer read as (SF_ltF) 5'-GAA CAT CTA CAC CCA AAA TYA C-3' and the reverse as (SF_ltR) 5'-TCT GAC CTG CCC GCT GAT TA-3'.

Each polymerase chain reaction (PCR) for both stonefly species was set up in $50 \mu \mathrm{l}$ as follows: $16 \mu \mathrm{l}$ of deionized water; $5 \mu l$ of each primer $(2.5 \mathrm{mM}) ; 5 \mu l$ of dNTPs $(5 \mathrm{mM})$; $10 \mu \mathrm{l}$ of $\mathrm{MgCl}_{2}(25 \mathrm{mM}) ; 0.2 \mu \mathrm{l}$ of Fisher Biotech Taq DNA

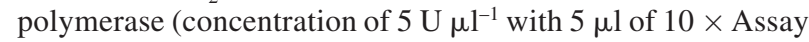
Buffer A) (Fisher Biotech, Australia), and $2 \mu \mathrm{l}$ of template DNA. PCR reactions were cycled 40 times in a Perkins Elmer GeneAmp PCR system 2400 (Perkin-Elmer Life, Waltham, MA). The PCR conditions were set with an initial denaturation phase of $5 \mathrm{~min}$ at $94{ }^{\circ} \mathrm{C}$ and all subsequent denaturations for $30 \mathrm{~s}$. The annealing phase was $30 \mathrm{~s}$ at $49{ }^{\circ} \mathrm{C}$, and extension was at $72{ }^{\circ} \mathrm{C}$ for $30 \mathrm{~s}$. After all cycles were completed a final extension for $7 \mathrm{~min}$ at $72{ }^{\circ} \mathrm{C}$ was performed.

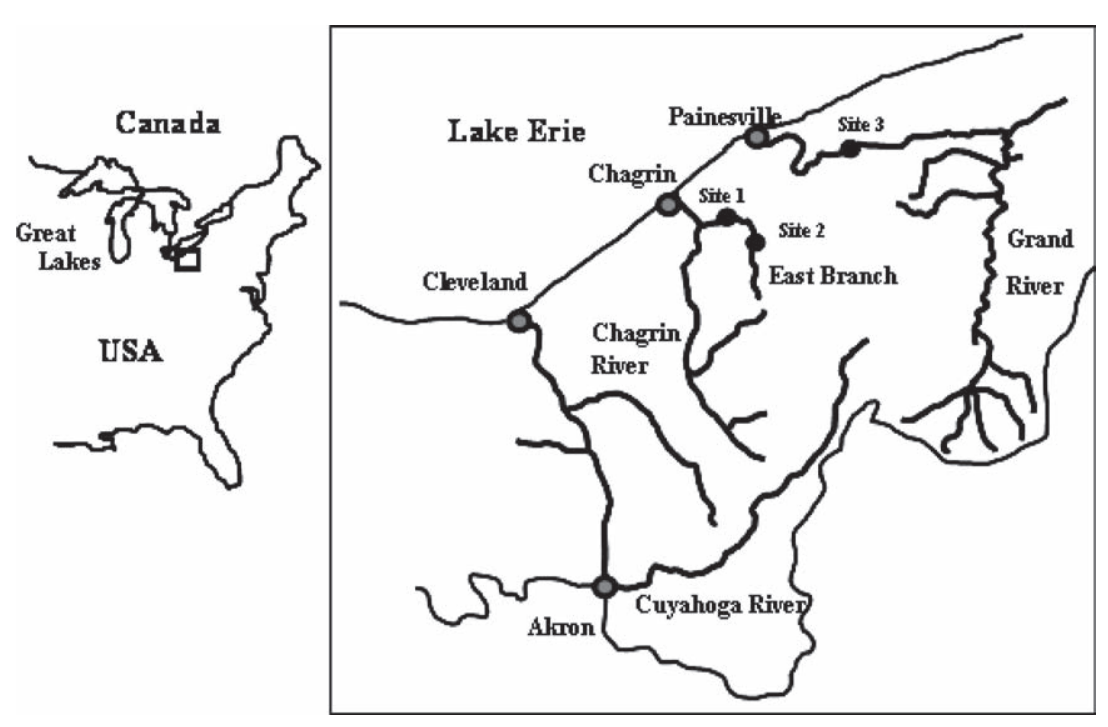

Fig. 1. The box indicates stonefly collecting sites within the Chagrin and Grand River Watersheds, Ohio, U.S.A. Circles represent sampling locations. 
The amplified DNA region was sequenced at Cleveland State University's DNA sequencing facility on a Beckman CEQ-8000 capillary autosequencer. All sequences were run in both the forward and reverse directions. Mitochondrial DNA sequences were aligned and read using the Sequencher software package (Sequencher vs. 4.0, Gene Codes Corp., Ann Arbor, MI) and conservatively screened by eye to eliminate any ambiguous scoring. Therefore, one was more likely to miss variation within a sequence than to score a false haplotype. Analysis of variation among haplotypes was performed with Arlequin v.3.01 (Excoffier et al., 2005), and the minimum spanning trees were produced by Network vs. 4.1.1.2 (Fluxus Technology Limited, Suffolk, U.K.).

\section{Results}

Tables 1 and 2 illustrate the diversity of haplotypes in both species for which gene and nucleotide diversity levels were similar. Distinct polymorphisms were common within the 16s rRNA region in both Allocapnia recta and Leuctra tenuis (accession numbers DQ915179-DQ915181). Between the Chagrin and Grand Rivers, the internal primers enabled accurate sequencing of a 492 base pair region of the mtDNA in 36 A recta specimens and of 459 bases from 30 individuals of L. tenuis. A BLAST search (Altschul et al., 1997) in GenBank using the most frequent haplotypes of both $A$. recta and L. tenuis best matched Pteronarcys princeps, the ebony salmonfly (accession number AY687866).

\section{Allocapnia recta}

Wright's FST scores for $A$. recta indicated that separation of samples between the two watersheds can explain $20 \%$ of the variation in haplotype diversity (Table $1, \mathrm{FST}=0.20 ; P<$ $0.05)$. This difference between samples from the Chagrin and Grand Rivers was significant. Over half of the specimens possessed one of two haplotypes (Table 1). The most common haplotype (H01) occurred frequently in both watersheds, but haplotype H02 $(n=8)$ was collected only once in the Chagrin River. Conversely, haplotype H03 $(n=5)$ was only observed in the Chagrin River. All other haplotypes were found once in one of the rivers. Overall gene and nucleotide diversities across the two watersheds were 0.83 and 0.67 respectively. Both gene and nucleotide diversities were consistently greater in the Chagrin River than in the Grand River (Table 1). This pattern is apparent in the minimum spanning tree where Chagrin River samples derived from one large and divided clade (Fig. 2).

Leuctra tenuis

In contrast to the results observed in A. recta, the FST score for samples of $L$. tenuis was 0.065 (Table 2, $P=0.14$, NS). The two most prevalent haplotypes were identified in samples from both watersheds, indicated that haplotypes in L. tenuis were randomly distributed between the rivers. Therefore, gene diversity varied little and no distinct clades occurred within the minimum spanning tree specific to either watershed (Fig. 3). The measure of nucleotide diversity in L. tenuis from each river, however, gave an unexpected result. Individuals of $L$. tenuis from the Chagrin River showed a significantly higher level of nucleotide diversity (0.95) than did specimens from the Grand River (0.38) (Table 2).

\section{Discussion}

The winter stonefly varied genetically between the neighbouring Chagrin and Grand Rivers in north-east Ohio, whereas the summer stonefly did not. Therefore the time of emergence or the reduced wing structure of $A$. recta, a much weaker flier (Marden et al., 2000), likely contributes to the limited ability of this species to disperse between the watersheds.

The ability of some stoneflies to disperse long distances is likely a function of wind speed. Allocapnia species have been observed to sail on the surface of the water using wind power to propel themselves from one location to another. As the adults emerge on mid-stream rocks or ice, they stand on top of the water surface tension, and raise their wings in response to gusts of wind, thus sailing to the shore (Marden $\&$ Kramer, 1995). Some members of the genus Allocapnia may also glide down from trees and other riparian vegetation during strong winds. Marden and Kramer (1995) determined that an insect with rudimentary wing structures such as A. recta, sailing across the water surface is more effective than gliding. Furthermore, temperature has an effect on the dispersal of winter stoneflies. Adult Allocapnia species were in higher abundance on sunny days when temperatures exceeded $5{ }^{\circ} \mathrm{C}$, with limited wind; during the harsher and colder days of winter, fewer adults were observed crawling along the snow (pers. obs.). Most sought cover under piles of

Table 1. Haplotype frequencies for Allocapnia recta as they relate to location. Single haplotypes were pooled. Gene diversity was estimated using Nei (1972), and nucleotide diversity was calculated using Arlequin v.3.01 (Excoffier et al., 2005). [H01, 02, etc. refers to haplotype number, $h$ (gene diversity), and $ð$ (haplotype diversity) SE (standard error)].

\begin{tabular}{|c|c|c|c|c|c|c|c|c|c|c|c|}
\hline Site & H01 & $\mathrm{H} 02$ & $\mathrm{H} 03$ & $\mathrm{H} 04$ & $\mathrm{H} 05$ & $\begin{array}{l}\text { Pooled single haplotypes } \\
\text { (H06-H12) }\end{array}$ & Totals & $\mathrm{h}$ & SE & ð $\times 100$ & $\mathrm{SE} \times 100$ \\
\hline Chagrin River & 7 & 1 & 5 & 2 & 0 & 5 & 20 & 0.85 & 0.01 & 0.68 & 0.09 \\
\hline Grand River & 5 & 7 & 0 & 0 & 2 & 2 & 16 & 0.73 & 0.02 & 0.52 & 0.08 \\
\hline Totals & 12 & 8 & 5 & 2 & 2 & 6 & 36 & 0.83 & 0.01 & 0.67 & 0.07 \\
\hline Haplotype frequencies & 0.33 & 0.22 & 0.14 & 0.06 & 0.06 & 0.03/each & & & & & \\
\hline
\end{tabular}


Table 2. Haplotype frequencies for Leuctra tenuis as they relate to location. Single haplotypes were pooled. Gene diversity was estimated using Nei (1972), and nucleotide diversity was calculated using Arlequin v.3.01 (Excoffier et al., 2005). [H01, 02, etc. refers to haplotype number, $h$ (gene diversity), and $\partial$ (haplotype diversity), SE (standard error)].

\begin{tabular}{|c|c|c|c|c|c|c|c|c|c|}
\hline Site & H01 & H02 & H03 & $\begin{array}{l}\text { Pooled single haplotypes } \\
\text { (H04-H10) }\end{array}$ & Totals & $\mathrm{h}$ & SE & ð $\times 100$ & $\mathrm{SE} \times 100$ \\
\hline Chagrin River & 6 & 5 & 0 & 4 & 15 & 0.76 & 0.02 & 0.95 & 0.14 \\
\hline Grand River & 7 & 1 & 4 & 3 & 15 & 0.74 & 0.02 & 0.38 & 0.07 \\
\hline Totals & 13 & 6 & 4 & 7 & 30 & 0.77 & 0.01 & 0.64 & 0.07 \\
\hline Haplotype frequencies & 0.43 & 0.20 & 0.13 & 0.03/each & & & & & \\
\hline
\end{tabular}

dead vegetation, woody debris, or snow packs on days of extreme cold temperatures.

Leuctra tenuis can disperse farther than A. recta. When summer air temperatures are less than $13{ }^{\circ} \mathrm{C}$, Leuctra stoneflies can use a hind-leg skimming mechanism to raise the body, and reduce drag on the water surface (Kramer \& Marden, 1997). On warmer days, L. tenuis flew over the stream searching for mates (pers. obs.). In addition to the mechanism of flight and temperature, the sample sites within the Chagrin and Grand Rivers are deeply incised channels, making transportation between streams difficult for even the stronger flying stoneflies.

Regardless of flight proficiency, few individuals will migrate across watersheds because adult gravid females remain near their natal streams to deposit their eggs after mating, while males will either search for other females for mating or die. This tendency not to disperse may restrict gene flow. While neonates, after hatching, may immediately start to swim downstream in search of food and to avoid predators (Kuusela \& Huusko,
1996), their movement is limited due to their size and they need not cross between rivers (Hughes et al., 1999; Schultheis et al., 2002).

One caveat of the results is the possibility that cryptic species were encountered that vary in mtDNA sequences rather than variation within each species. In $A$. recta, three haplotype clades occurred in the samples from the Chagrin River, but only two in the Grand River, and in L. tenuis, Grand River samples predominantly possessed haplotypes basal within the observed clade. If a cryptic sibling species was present in the Chagrin River that was responsible for the apparent population structure, conclusions about dispersal would be unchanged; variation in Allocapnia instead would suggest structure at a community rather than a population level.

As a final note, in salamanders, fish and arthropods, populations in previously glaciated regions tend to have less genetic variation than their populations of origin (Tilley, 1997; Bernatchez \& Wilson, 1998; Reiss et al., 1999), a pattern

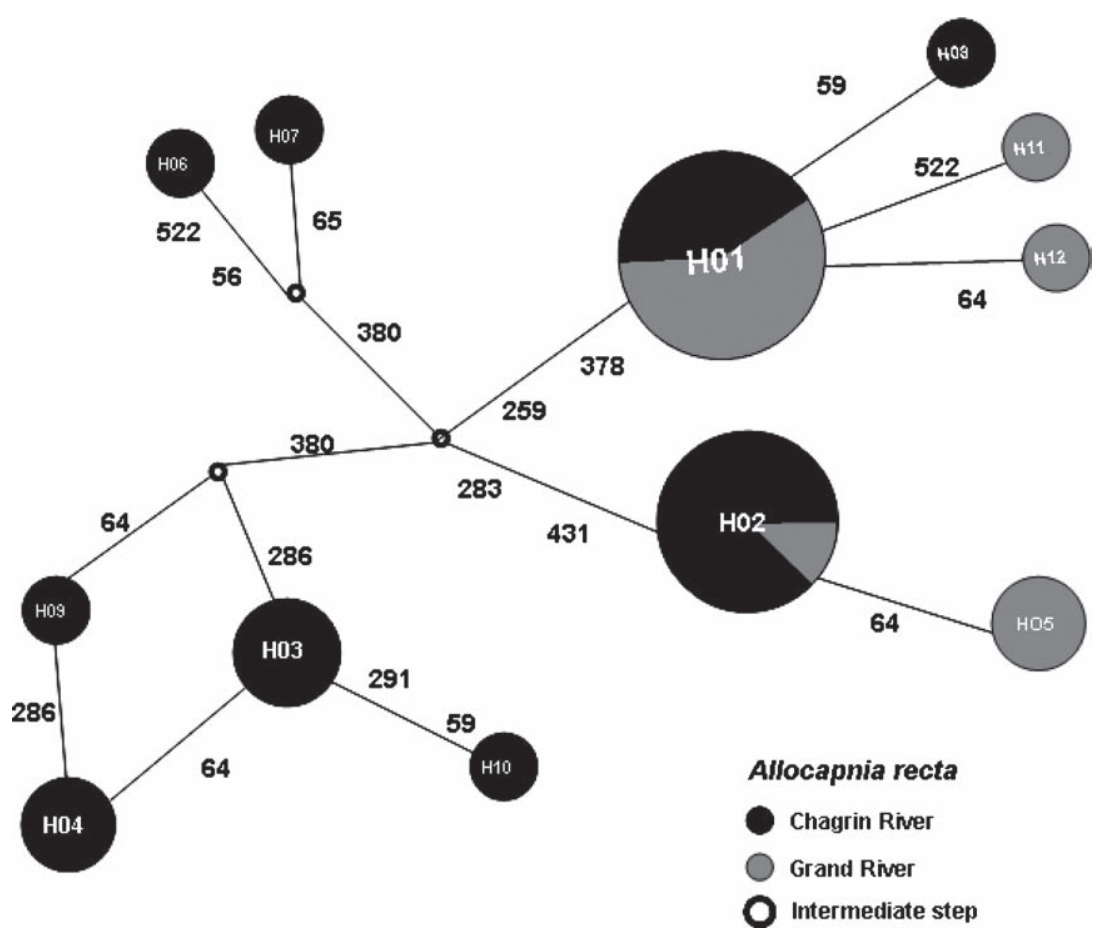

Fig. 2. Haplotypes of Allocapnia recta in the Chagrin and Grand Rivers. Circle diameter represents the sample size of each haplotype and levels of shading denote the frequency either in the Chagrin River (black) or Grand River (grey). Numbers indicate the base position changed in the sequence. 
Fig. 3. Haplotypes of Leuctra tenuis in the Chagrin and Grand Rivers. Circle diameter represents the sample size of each haplotype and levels of shading denote the frequency either in the Chagrin River (black) or Grand River (grey). Numbers indicate the base position changed in the sequence.

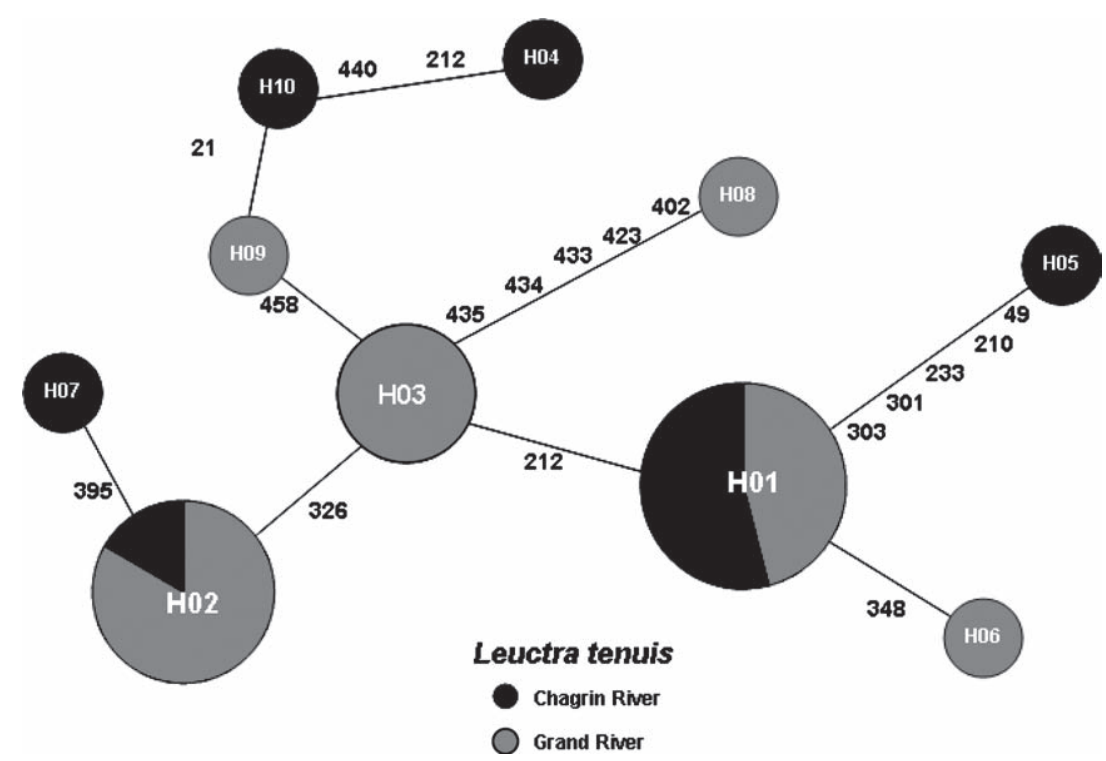

consistent with the lower genetic variation found in the Grand River than in the Chagrin River samples.

\section{Acknowledgements}

This work was made possible by support provided to R.K. by an Established, Full-time, Faculty Research Development from Cleveland State University and J.W. through New Faculty Development funding. Support was also provided to A.Y. by the Doctoral Dissertation Research Expense Award from CSU and from the Cleveland Museum of Natural History. The authors also thank Holden Arboretum for access to the Chagrin sampling sites.

\section{References}

Altschul, S.F., Madden, T.L., Schäffer, A.A., Zhang, J., Zhang, Z., Miller, W. \& Lipman, D.J. (1997) Gapped BLAST and PSI-BLAST: a new generation of protein database search programs. Nucleic Acids Res., 25, 3389-3402.

Bernatchez, L. \& Wilson, C.C. (1998) Comparative phylogeography of Nearctic and Palearctic fishes. Molecular Ecology, 7, 431-452.

Bohonak, A.J. \& Jenkins, D.G. (2003) Ecological and evolutionary significance of dispersal by freshwater invertebrates. Ecological Letters, 6. 783-796.

Briers, R.A., Gee, J.H.R., Cariss, H.M. \& Geoghegan, R. (2004) Interpopulation dispersal by adult stoneflies detected by stable isotope enrichment. Freshwater Biology, 49, 425-431.

DePietro, R., Lombardo, B.M. \& Viglianisi, F. (1997) Genetic diversity in some species of Hydropsyche (Tricoptera, Hydropsychidae) in central and southern Italy. Italian Zoology, 64, 31-39.

Excoffier, L.G., Laval, G. \& Schneider, S. (2005) Arlequin, Version 3.0: An integrated software package for population genetics data analysis. Evolutionary Bioinformatics Online, 1, 47-50.

Frison, T.H. (1942) Studies of North American Plecoptera: with special references to the fauna of Illinois. Illinois Bulletin, 22, 235-355.
Gaston, K.J. (1994) Rarity. Chapman \& Hall, London.

Hughes, J.M., Mather, P., Sheldon, A.L. \& Allendorf, F.W. (1999) Genetic structure of the stonefly, Yoraperla brevis, populations: the extent of gene flow among adjacent montane streams. Freshwater Biology, 41, 63-72.

Kramer, M.G. \& Marden, J.H. (1997) Almost airborne. Nature, 385, 403-404.

Kuusela, K. \& Huusko, A. (1996) Post-emergence migration of stoneflies (Plecoptra) into the nearby forest. Ecological Entomology, 21, 171-177.

Malmqvist, B. (2000) How does wing length relate to distribution patterns of stoneflies (Plecoptera) and mayflies (Ephemeroptera)? Biological Conservation, 93, 271-276.

Marden, J.H. \& Kramer, M.G. (1995) Locomotor performance of insects with rudimentary wings. Nature, 377, 332-334.

Marden, J.H., O’Donnell, B.C., Thomas, M.A. \& Bye, J.Y. (2000) Surface skimming stoneflies and Mayflies: The taxonomic and mechanical diversity of two-dimensional aerodynamic locomotion. Physiological and Biochemical Zoology, 73, 751-764.

Miller, M.P., Blinn, D.W. \& Keim, P. (2002) Correlations between observed dispersal capabilities and patterns of genetic differentiation in populations of four aquatic insect species from the Arizona White Mountains, U.S.A. Freshwater Biology, 47, 1660-1673.

Monaghan, M.T., Spakk, P., Robinson, C.T. \& Ward, J.V. (2002) Population genetic structure of three alpine stream insects influences of gene flow, demographics, and habitat fragmentation. Journal of North American Benthological Society, 21, 114-131.

Monaghan, M.T., Robinson, C.T., Saak, P. \& Ward, J.V. (2005) Macroinvertebrate diversity in fragmented Alpine streams: implications for freshwater conservation. Aquatic Sciences, 67, 454-464.

Nebeker, A.V. \& Gaufin, A.R. (1967) Factors affecting wing length and emergence in the winter stonefly Capnia nana. Entomological News, 4, 85-92.

Nei, M. (1972) Genetic distance between populations. American Naturalist, 106, 283-292.

Palumbi, S.R. (1997) Nucleic acids II: the polymerase chain reaction. In: Molecular Systematics, 2nd edn (ed. by D. M. Hillis, C. Moritz and B. K. Mable), pp. 205-247, Sinauer Associates, Sunderland, Massachusetts. 
Petersen, I., Masters, Z., Hildrew, A.G. \& Ormerod, S.J. (2004) Dispersal of adult aquatic insects in catchments of differing land use. Journal of Applied Ecology, 41, 934-950.

Reiss, R.A., Ashworth, A.C. \& Schwert, D.S. (1999) Molecular genetic evidence of post-Pleistocene divergence of populations of the artic-alpine ground beetle Amara alpine (Paukull) (Coleoptra: Carabidae). Journal of Biogeography, 26, 785-794.

Ross, H.H. \& Ricker, W.E. (1971) The Classification, Evolution. and Dispersal of the Winter Stonefly Genus Allocapnia. Illinois Biological Monographs. University of Illinois Press, Chicago, Illinois.

Sanderson, R.A., Eyre, M.D. \& Rushton, S.P. (2005) The influence of stream invertebrate composition at neighbouring sites on local assemblage composition. Freshwater Biology, 50, 221-231.
Schultheis, A.S., Hedricks, A.C. \& Weigt, L.A. (2002) Gene flow, dispersal, and nested clade analysis among populations of the stonefly Peltoperla tarteri in the southern Appalachians. Molecular Ecology, 11, 317-327.

Smith, P.J., McVeagh, S.M. \& Collier, K.J. (2006) Genetic diversity and historical population structure in the New Zealand mayfly Acanthophlebia cruentata. Freshwater Biology, 51, 12-24.

Stark, B.P., Szczytko, S.W. \& Nelson, C.R. (1998) American Stoneflies: a Photographic Guide to Plecopterans. The Caddis Press, Columbus, Ohio.

Tilley, S.G. (1997) Patterns of genetic differentiation in Appalachian desmognathine salamanders. Journal of Heredity, 88, 305-315. 